\title{
Proximate Effect of Drying on the Qualities of Local Cheese Dried With Freeze Dryer
}

\author{
Okafor J.O., ${ }^{2}$ Adamu, $\mathrm{M}^{1}$. andTsado D.G ${ }^{1}$. \\ ${ }^{l}$ Department of chemical Engineering, Federal Polytechnic, P.M.B. 55, Bida. Niger State, Nigeria. \\ ${ }^{2}$ Department of Chemical Engineering, Federal University of Technology, P.M.B. 65, Minna.
}

Niger State, Nigeria.

\begin{abstract}
Three different samples of cheese were used to investigate the effect of freeze drying on the nutritional content of local cheese. Sample A was obtained from Bida in Niger state. While samples B and C are obtained from Suleja and Kontagora respectively all in Niger state. The results of the proximate analysis showed that sample A with initial moisture content of 0.62 has a calorific value (calculated from the amount of carbohydrate, protein and fat) of $557.01 \mathrm{Kcal} / 100 \mathrm{~g}$ after freeze drying at a temperature of $25^{\circ} \mathrm{C}$ and a chamber pressure of $2.7 \mathrm{~N} / \mathrm{m}^{2}$ for 5 hours. This is above the minimum recommended standard value of 465 Kcal/100g by Food and Agricultural Organization (FAO) and World Health Organization (WHO) for Milk and dairy products. The calcium content was $311 \mathrm{mg}$ lower than the minimum standard value of $1000 \mathrm{mg}$ by FAO and WHO. Samples B and C have calorific values of $511.2 \mathrm{Kcal} / 100 \mathrm{~g}$ and $560 \mathrm{Kcal} / 100 \mathrm{~g}$ after freeze drying at $25^{\circ} \mathrm{C}, 27 \mathrm{~N} / \mathrm{m}^{2}$ and 5 hours respectively. These are both above the minimum recommended standard value. The calcium contents for both samples $B$ and C are $311 \mathrm{mg}$ and $304 \mathrm{mg}$ respectively which in both cases are lower than the standard minimum stipulated value by $F A O$ and WHO. With these results, freeze drying can be a good option for drying local cheese in order to retain its nutrients and also increase its shelf-life for later human consumption.
\end{abstract}

Keywords: Local Cheese, Freeze drying, proximate analysis.

\section{Introduction}

The demand for dairy products in sub-Saharan Africa increased with the overall growth rate in the consumption of milk and milk products and the growth in demand is estimated at about $2.1 \%$ per year(Charles, 1993).This increasing demand for milk and dairy products is an opportunity and potential for the small scale milk producer and for the development of the milk production and processing industry(Charles, 1993). Raw milk at ambient temperature of $25^{\circ} \mathrm{C}$ and above has a shelf- life of a minimum of 2 hours to a maximum of 24 hours depending on the temperature of storage, nature of storage and the moisture content of the milk. When raw milk is processed into local cheese, its moisture content reduces from $87 \%$ to $65 \%$ and this improves the shelf-life to about 4 to 5 days depending on the temperature of storage. Local Cheese therefore provides an ideal vehicle for preserving the valuable nutrients in milk and making them available for only few days (Charles, 1993). Local Cheese is an essential source of carbohydrate, protein, fat and calcium and therefore it is an important food in the diet of both old and young people (Africa and Susana, 2011).Water (moisture) content is usually the major component of food materials and has a direct and significant effect on their quality and shelf life through its influence on several physicochemical and biological changes (Africa and Susana, 2011). Drying is the effective means of controlling the moisture contents of food materials.

Drying is the oldest method of food preservation which results in the reduction of the moisture content and consequently water activity in order to achieve physicochemical and biological stabilization (Warren, Julius and Peter, 2005).The quality of food products may be partially or totally affected by drying processes. Various changes occur in physical, chemical and/ or biological characteristics of food products during drying process, storage and distribution (Ratti, 2001). These changes affect the physical properties such as colour, texture and structure. They can also result into undesirable biochemical reactions such as deterioration of aroma compounds or devaluation of nutritional substances especially in fruits and vegetables (Ratti, 2001).

Sun drying is practiced by Farmers to dry crops particularly (date and tomato) by spreading them on mats, paved ground or in the field, to expose them to the sun. This process is not very hygienic. It depends on weather conditions and there is a risk of deterioration (Bala et al., 2003). Air drying is an ancient method used in preserving foods during which the solid to be dried is exposed to a continuous stream of hot air that removes moisture content of the food materials by evaporation (Ratti, 2001). There are different types of drying reported in literature. These include spray drying, tunnel drying, pneumatic drying, tray drying, drum drying, fluidized bed drying, rotary drying, freeze drying and shelf drying (Richardson et al., 2002; Marco et al., 2010; Stephan et al., 2011; Erenturk, 2007; Mezherichera et al., 2010). All these are different forms of air drying categorised according to the nature of material been dried, the method of heat supply, and the way materials flow in the 
dryer. Air drying results in dehydrated products that can have an extended life of a year, however, the quality of the dried product is usually reduced when compared with that of the original material (Ratti, 2001).

One of the recently developed technologies of drying is freeze-drying (Nastaj and Witkiewicz, 2009).Freeze-drying is the process that takes place when water or another solvent is removed from a frozen product by sublimation under low temperature and pressure (Salvatore and Antonello, 2008). Sublimation occurs when a frozen liquid or solvent changes directly from solid phase to the gaseous phase without passing through the liquid phase. Ice sublimes under vacuum condition and low temperature as opposed to what happens in sublimation under atmospheric condition. During freeze drying, as the ice sublimes under vacuum condition, it leaves pores in the dry residual material making it easy to re-hydrate and retain its original properties (Salvatore and Antonello, 2008).Properly freeze-dried products can retain their qualities such as aroma, texture, structural integrity and flavour and can be preserved at ambient temperatures for years (Chakraborty et al., 2006). This present study is focus on the investigation of the influence of freeze drying on the nutritional value of local cheese. This will be achieved via proximate analysis of the fresh and dried product.

\subsection{Materials}

\section{Materials and Methods}

Fresh local cheeses were purchased from markets located in Bida, Suleja and Kontagora in Niger state are used for the research. All the chemicals used in this study are of analytical grades and includes: $\mathrm{H}_{2} \mathrm{SO}_{4}(98 \%)$, anhydrous $\mathrm{Na}_{2} \mathrm{SO}_{4}, \mathrm{CuSO}_{4}, \mathrm{CaCO}_{3}$, boric indicator, Dilute $\mathrm{HCl}$, Concentrated $\mathrm{HNO}_{3}$, Perchloric Acid and Petroleum Ether.

\subsection{Methodology}

The fresh cheese sample was cut into rectangular shapes of dimensions $0.035 \mathrm{~m} \times 0.025 \mathrm{~m} \times 0.02 \mathrm{~m}$ and each sample was weighed and placed on a clean crucible. The crucible and its contents were then transferred to a freezer operating at $-20^{\circ} \mathrm{C}$ (Thermo-cool HR-170 T) for 8 hours. The frozen cheese was then placed in the drying chamber of the freeze dryer (armfield, Refrigerant 502). The vacuum pump (Javac J D-120) was then switched on. At a fixed chamber pressure of $26.7 \mathrm{~N} / \mathrm{m}^{2}$ and a fixed drying time of 1 hour, the chamber temperature was varied using $5^{\circ} \mathrm{C}, 10^{\circ} \mathrm{C}, 15^{\circ} \mathrm{C}, 20^{\circ} \mathrm{C}$ and $25^{\circ} \mathrm{C}$. At the end of each experiment, the dried cheese was removed and weighed using an electronic weighing balance (Adventure ARRW 60) and the moisture removed was calculated. The temperature of $25{ }^{\circ} \mathrm{C}$ that gave the highest moisture loss and less effect on the nutritional content was fixed (Richardson et al., 2002).The experiment was continued by increasing the drying time at intervals of 1 hour until the moisture content is not more than $5 \%$ or a constant weight of the dried cheese was obtained (Emmanuel, 2010). The dried cheese was then analysed to determine the protein, fat, calcium, fibre, ash, energy value and carbohydrate.

The protein content was determined using Kjeldhal method. The sample was first digested by placing about $2 \mathrm{~g}$ of the sample and one tablet of Kjeldhal catalyst in a digestion flask after which $25 \mathrm{~cm}^{3}$ of concentrated $\mathrm{H}_{2} \mathrm{SO}_{4}$ was added to it. The digestion flask was then transferred to Kjeldhal micro distillation unit and heated to a temperature of $150{ }^{\circ} \mathrm{C}$ in a fume cupboard for 1 hour and then the temperature raised to $350{ }^{\circ} \mathrm{C}$ for another 2.5 hours after which a clear digest was obtained. The digest was transferred to a Kjeldhal distillation flask and $20 \mathrm{ml}$ of $40 \% \mathrm{NaOH}$ solution was added to it followed by $10 \mathrm{ml}$ of distilled water. $10 \mathrm{ml}$ of boric indicator was placed in a conical flask meant to collect ammonia gas during distillation. The Kjeldhal distillation unit was then assembled and distillation carried out until $40 \mathrm{ml}$ of distillate was collected. The distillate was then titrated against $0.1 \mathrm{M} \mathrm{HCl}$ until the green colour of the indicator turns pink. The $\%$ Nitrogen was calculated using equation(1) (Gregory, 2005).

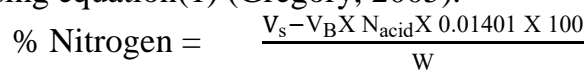

where

$\mathrm{V}_{\mathrm{S}}=$ Volume of acid required to titrate sample $(\mathrm{ml})$

$\mathrm{V}_{\mathrm{B}}=$ Volume of acid required to titrate blank (ml)

$\mathrm{N}_{\text {acid }}=$ Normality of acid $(0.1 \mathrm{M})$

$\mathrm{W}=$ weight of sample $(\mathrm{g})$

The percentage Nitrogen obtained from Equation (1) was used to calculate the percentage protein content of the dried cheese using Equation (2).

$$
\% \text { Protein }=\% \text { Nitrogen } \times 6.25
$$

The Fat content was determined using Soxhlet fat extraction method. This method employs extraction of fat from food with a non-polar organic solvent (petroleum ether) for 1 hour. The fat content was calculated using the relationship in Equation (3) (Gregory, 2005).

$$
\% \text { fat }=\frac{\text { weight of Fat }}{\text { weight of sample }} \times 100 \text { (3) }
$$


The calcium content was determined using Atomic absorption spectrophotometer. About $1.0 \mathrm{~g}$ of the sample is first digested with $20 \mathrm{ml}$ of acid mixture $\left(650 \mathrm{ml}\right.$ concentrated $\mathrm{HNO}_{3} ; 80 \mathrm{ml}$ perchloric acid (PCA); 20ml $\mathrm{H}_{2} \mathrm{SO}_{4}$ ) and aliquots of the diluted clear digest used for atomic absorption spectrophotometery using filters that match the different elements (Gregory, 2005).

The fibre content was determined by the Hennenberg method (Gregory, 2005). About $5 \mathrm{~g}$ of cheese sample was de-fated in a soxhlet apparatus using petroleum ether. The residue was then boiled under reflux for 30 minutes with $100 \mathrm{ml}$ of $1.25 \mathrm{M} \mathrm{H}_{2} \mathrm{SO}_{4}$ after which the mixture was filtered. The residue was washed with distilled water after which it was treated with $100 \mathrm{ml} 1.25 \mathrm{M} \mathrm{NaOH}$ solutions and then filtered. The residue was then dried and weighed and this represents the fibre content (Gregory, 2005).

The ashing of cheese sample was done in a muffle furnace at $550{ }^{\circ} \mathrm{C}$ until a whitish or grey deposit of ash was obtained. The amount of ash was calculated as the percentage of wet sample (Gregory, 2005).

The carbohydrate content was determined by difference method as reported by Gregory, (2005). This was obtained by calculation after estimating all other fractions by proximate analysis.

$\%$ carbohydrate $=100-(\%$ moisture $+\%$ Ash $+\%$ Protein $+\%$ Fibre $)$

The energy value(calorific value) was calculated using the relationship in Equation (5) (Gregory, 2005).

Energy value $=(\%$ carbohydrate $x 4)+(\%$ protein $x 4)+(\%$ Fat $x 9)$

\section{Results And Discussion}

Conventional drying methods may partially or totally affect the quality of a product depending on the drying method and parameters such as temperature. Various changes in physical, chemical and/ or biological characteristics of food materials can take place during drying processes, storage and distribution. These changes affect the physical properties such as colour, structure and biochemical properties such as degradation of nutritional substances most especially in fruits and vegetables. Based on these, the effects of freeze drying on the nutritional content of cheese were investigated.

Proximate analysis was carried out on all samples of cheese before and after freeze drying. The major constituents analyzed are moisture contents, fats, protein, Carbohydrate, fibre contents, ash contents and calcium. The analysis was done on samples dried at different drying temperatures in order to investigate the effect of drying temperature on the nutritional contents of the cheese. The results obtained for sample $\mathrm{A}$ is presented in Table 1. From the results, the initial moisture content was $62 \%$ and as the freeze drying temperature increases from 278 to $298 \mathrm{~K}$, the moisture content decreases with the lowest value of $42 \%$ recorded at the highest freeze drying temperature of $298 \mathrm{~K}$ after drying all samples for one hour. This is because increase in temperature increases the rate of sublimation of the ice in the frozen cheese. The results also reveal that as the moisture content decreases, the percentage composition of fat increases steadily from 17.60 to $19.89 \%$ at temperature range of 278 to $298 \mathrm{~K}$ due to removal of moisture which is the major constituent. In a similar manner, the percentage compositions of protein and carbohydrate increases from 15.90 to $17.69 \%$ and 18.30 to $19.62 \%$ respectively. A negligible composition of $0.05 \%$ fibre was noticed before freeze drying and this value became un-noticed after each of the drying process. The ash contents changes inconsistently in all the samples tested and this may be as a result of non uniform distribution of fragments of Calotropisprocera plant used as coagulant in the production of local cheese. As expected, the energy value which is the measure of Carbohydrate, protein, and fats increases from a lower value of $212.45 \mathrm{Kcal} / 100 \mathrm{~g}$ to a higher value of 328.25 $\mathrm{kcal} / 100 \mathrm{~g}$ at temperatures of $278 \mathrm{~K}$ and $298 \mathrm{~K}$ respectively. This is because of the increase in concentration of Carbohydrate, protein and fat due to significant reduction in moisture content. The calcium content remains at an approximate constant value of $0.3 \mathrm{~g}$ which signifies no negative effects on nutritional contents of cheese throughout the temperature range.

Table 1: Proximate analysis of sample (A) before and after freeze drying at various temperatures

\begin{tabular}{|c|c|c|c|c|c|c|c|c|c|c|}
\hline $\mathrm{S} / \mathrm{N}$ & Sample & $\begin{array}{l}\text { Temp } \\
\left({ }^{\circ} \mathrm{C}\right)\end{array}$ & $\begin{array}{l}\text { moisture } \\
(\%)\end{array}$ & $\begin{array}{l}\text { Fat } \\
(\%)\end{array}$ & $\begin{array}{l}\text { crude protein } \\
(\%)\end{array}$ & $\begin{array}{c}\text { Crude fibre } \\
(\%)\end{array}$ & $\begin{array}{l}\text { Ash } \\
(\%)\end{array}$ & $\begin{array}{c}\mathrm{CHO} \\
(\%)\end{array}$ & $\begin{array}{l}\text { Energy } \\
\text { Value (Kcal) }\end{array}$ & $\begin{array}{l}\text { calcium } \\
\text { (g) }\end{array}$ \\
\hline Before: & : control & - & 62.10 & 13.57 & 10.62 & 0.05 & 1.7 & 11.96 & 212.45 & 0.305 \\
\hline \multicolumn{11}{|l|}{ After: } \\
\hline 1 & $A_{1}$ & 5 & 46.70 & 17.60 & 15.90 & $\mathrm{Nd}$ & 1.5 & 18.30 & 295.20 & 0.311 \\
\hline 2 & $\mathrm{~A}_{2}$ & 10 & 45.50 & 18.11 & 16.70 & $\mathrm{Nd}$ & 1.2 & 18.49 & 303.75 & 0.304 \\
\hline 3 & $\mathrm{~A}_{3}$ & 15 & 44.10 & 18.61 & 17.23 & $\mathrm{Nd}$ & 1.4 & 18.66 & 311.59 & 0.312 \\
\hline 4 & $\mathrm{~A}_{4}$ & 20 & 43.14 & 19.22 & 17.54 & $\mathrm{Nd}$ & 1.0 & 19.10 & 319.54 & 0.321 \\
\hline 5 & $\mathrm{~A}_{5}$ & 25 & 42.00 & 19.89 & 17.69 & $\mathrm{Nd}$ & 0.8 & 19.62 & 328.25 & 0.315 \\
\hline
\end{tabular}

*Nd: Not detectable 
The results of the proximate analysis performed on sample B with initial moisture content of $69 \%$ is expressed in Table 2. As can be seen from the Table, the results followed the same trend with that of sample A. After drying for one hour at a freeze drying temperature of $278 \mathrm{~K}$ the moisture content reduce to $52.6 \%$. The minimum moisture content of $48 \%$ was recorded at the highest freeze drying temperature of $298 \mathrm{~K}$ after the same drying time of one hour. In a similar manner with sample A and obviously due to the same reason, as the moisture is removed with increase in freeze drying temperature, the percentage compositions of fat, protein, and carbohydrate increase from 12.16 to $17.15 \%, 9.16$ to $14.77 \%$ and 14.13 to $18.83 \%$ respectively at a temperature range of 278 to $298 \mathrm{~K}$. There is also an in consistent change in the ash content and the energy value increases steadily from 202.60 to $292.75 \mathrm{Kcal}$ due to increase in percentage compositions of fat, protein and carbohydrate. The calcium content also remains at an approximate constant value of $0.3 \mathrm{~g}$

Table 2: Proximate analysis of sample (B) before and after freeze drying at various temperatures

\begin{tabular}{|c|c|c|c|c|c|c|c|c|c|c|}
\hline $\mathrm{S} / \mathrm{N}$ & Sample & $\begin{array}{r}\text { Temp } \\
\left({ }^{\circ} \mathrm{C}\right)\end{array}$ & $\begin{array}{c}\text { moisture } \\
(\%)\end{array}$ & $\begin{array}{l}\text { Fat } \\
(\%)\end{array}$ & $\begin{array}{c}\text { crude protein } \\
(\%)\end{array}$ & $\begin{array}{c}\text { Crude fibre } \\
(\%)\end{array}$ & $\begin{array}{l}\text { Ash } \\
(\%)\end{array}$ & $\begin{array}{r}\mathrm{CHO} \\
(\%)\end{array}$ & $\begin{array}{l}\text { Energy } \\
\text { Value (Kcal) }\end{array}$ & $\begin{array}{c}\text { calcium } \\
\text { (g) }\end{array}$ \\
\hline Before & Control & - & 69.80 & 12.16 & 9.16 & 0.05 & 1.70 & 14.13 & 202.60 & 0.316 \\
\hline \multicolumn{11}{|l|}{ After: } \\
\hline 1 & $\mathrm{~B}_{1}$ & 5 & 52.60 & 15.20 & 14.81 & $\mathrm{Nd}$ & 1.33 & 16.06 & 260.28 & 0.308 \\
\hline 2 & $\mathrm{~B}_{2}$ & 10 & 50.82 & 15.40 & 15.07 & $\mathrm{Nd}$ & 1.50 & 18.21 & 271.72 & 0.302 \\
\hline 3 & $\mathrm{~B}_{3}$ & 15 & 49.85 & 15.83 & 15.39 & $\mathrm{Nd}$ & 1.50 & 18.43 & 277.75 & 0.310 \\
\hline 4 & $\mathrm{~B}_{4}$ & 20 & 48.92 & 16.76 & 15.51 & $\mathrm{Nd}$ & 1.20 & 18.61 & 287.32 & 0.321 \\
\hline 5 & $\mathrm{~B}_{5}$ & 25 & 48.00 & 17.15 & 14.77 & $\mathrm{Nd}$ & 1.25 & 18.83 & 292.75 & 0.316 \\
\hline
\end{tabular}

*Nd: Not detectable

From Table 3, the initial moisture content of sample $\mathrm{C}$ was $52.15 \%$. When dried at freeze drying temperature of $278 \mathrm{~K}$ for one hour, the moisture content reduces to $39.25 \%$. The percentage composition of moisture reduces steadily with increase in freeze drying temperature with a minimum value of $34 \%$ at the highest temperature of $298 \mathrm{~K}$. As a result of the moisture losses, the compositions of fat, protein and carbohydrate increases as usual which consequently results in increase in energy value from an initial value of $263.55 \mathrm{Kcal}$ before freeze drying to $341.51 \mathrm{Kcal}$ after freeze drying at $278 \mathrm{~K}$ for a period of one hour. As the drying temperature is increased, the energy value increases with the maximum value of $379.65 \mathrm{Kcal}$ recorded at $298 \mathrm{~K}$. The negligible $0.05 \%$ crude fibre before freeze drying disappeared in all the dried samples while the change in ash content was in consistent in all the dried samples. As observed in samples A and B the calcium content remains at an approximate value of $0.3 \mathrm{~g}(300 \mathrm{mg})$.

Table 3: Proximate analysis of sample (C) before and after freeze drying at various temperatures

\begin{tabular}{|c|c|c|c|c|c|c|c|c|c|c|}
\hline $\mathrm{S} / \mathrm{N}$ & Sample & $\begin{array}{r}\text { Temp } \\
\left({ }^{\circ} \mathrm{C}\right)\end{array}$ & $\begin{array}{c}\text { moisture } \\
(\%)\end{array}$ & $\begin{array}{l}\text { Fat } \\
(\%)\end{array}$ & $\begin{array}{c}\text { crude protein } \\
(\%)\end{array}$ & $\begin{array}{c}\text { Crude fibre } \\
(\%)\end{array}$ & $\begin{array}{l}\text { Ash } \\
(\%)\end{array}$ & $\begin{array}{r}\mathrm{CHO} \\
(\%)\end{array}$ & $\begin{array}{l}\text { Energy } \\
\text { Value (Kcal) }\end{array}$ & $\begin{array}{c}\text { calcium } \\
\text { (g) }\end{array}$ \\
\hline Before: & : Control & - & 52.15 & 15.67 & 22.67 & 0.05 & 1.50 & 7.96 & 263.55 & 0.301 \\
\hline \multicolumn{11}{|l|}{ After: } \\
\hline 1 & $\mathrm{C}_{1}$ & 5 & 39.25 & 20.43 & 27.05 & $\mathrm{Nd}$ & 0.91 & 12.36 & 341.51 & 0.311 \\
\hline 2 & $\mathrm{C}_{2}$ & 10 & 37.75 & 22.40 & 26.53 & $\mathrm{Nd}$ & 0.64 & 12.68 & 358.44 & 0.313 \\
\hline 3 & $\mathrm{C}_{3}$ & 15 & 36.80 & 22.90 & 26.83 & $\mathrm{Nd}$ & 0.32 & 13.15 & 366.02 & 0.289 \\
\hline 4 & $\mathrm{C}_{4}$ & 20 & 35.10 & 23.49 & 26.90 & $\mathrm{Nd}$ & 0.50 & 14.01 & 375.05 & 0.301 \\
\hline 6 & $\mathrm{C}_{5}$ & 25 & 34.00 & 23.74 & 27.12 & $\mathrm{Nd}$ & 0.70 & 14.40 & 379.65 & 0.304 \\
\hline
\end{tabular}

*Nd: Not detectable 
When the results of Samples A, B, and C are compared it was observed that the compositions of fat is greater, followed by that of protein and then carbohydrate in Samples A and B. In sample C, the composition of protein is greater, followed by that of fat and then carbohydrate. This disparity in compositions of cheese may be attributed by the difference in the compositions of cow milk (obtained from different varieties of cows) which is the major raw material used in cheese making. It was also observed that Sample C, with initial moisture content of $52.15 \%$ has the highest energy values of the dried samples followed by sample A with initial moisture content of $62.1 \%$ and then sample B with initial moisture content of $69.8 \%$. This implies that the nutritive value is controlled by the amount of moisture present in the final product which is favoured by moisture removal, an important factor for food storage that prevents food degradation by bacterial activities.

Following the results of the proximate analysis obtained from the investigation of effect of freeze drying temperature on the nutritive content of cheese, a working temperature of $298 \mathrm{~K}$ (The temperature that gave the highest moisture loss) was chosen to investigate the effect of freeze drying time on the nutritive content. All the three samples were dried over a period of five hours and the compositions compared with the standards recommended by Food and Agricultural Organization (FAO) and World health Organization (WHO), (2002). From Table 4, considering sample A with an initial moisture content of $62.1 \%$, the final moisture content of $5.01 \%$ was recorded after five hours of drying. This is a little less than the minimum $4 \%$ recommended standard by FAO and WHO for milk and milk products. The fat content of the final product was $35.41 \%$ which is greater than the minimum standard value of $24 \%$. A composition of $28.02 \%$ protein was recorded which is greater than the minimum recommended standard of $26 \%$. The carbohydrate content was $31.56 \%$ which is less than the minimum recommended standard value of $38 \%$. The energy value which is the measure of the overall major nutrients was $557.01 \mathrm{Kcal} / 100 \mathrm{~g}$ of sample which is greater than the minimum recommended standard value of $465 \mathrm{Kcal} / 100 \mathrm{~g}$. The calcium content was $311 \mathrm{mg}$ which is lower than the standard value of $1000 \mathrm{mg}$. Sample B with an initial moisture content of $45 \%$ was completely dried after 5 hours drying with a final moisture content of $0 \%$. After the drying, the compositions by mass of fat, protein and carbohydrates are $23.04 \%, 27.42 \%$ and $48.54 \%$ respectively. The fat content almost agrees with the minimum standard value while the protein and carbohydrate are greater than the minimum standard values. The energy value of $511.2 \mathrm{Kcal} / 100 \mathrm{~g}$ is good while the calcium content of $310 \mathrm{mg}$ is below standard. For sample $\mathrm{C}$ with initial moisture content of $52 \%$, the final moisture content of $0 \%$ is excellent for storage, and fat and protein contents of $32.96 \%$ and $38.90 \%$ are above the minimum standard values while the carbohydrate content of $27.14 \%$ is below standard. The calorific value of $560.80 \mathrm{Kcal} / 100 \mathrm{~g}$ is really acceptable, but the calcium content of $304 \mathrm{mg}$ is not satisfactory.

Table 4 Proximate analysis for samples (A),(B) and(C) before and after freeze drying for 5 hours at a chamber pressure of $26.7 \mathrm{~N} / \mathrm{m}^{2}$ and sublimation temperature of $298 \mathrm{~K}\left(25^{\circ} \mathrm{C}\right)$

\begin{tabular}{|c|c|c|c|c|c|c|c|c|c|}
\hline \multicolumn{2}{|c|}{ Sample } & $\begin{array}{c}\text { Moisture } \\
(\%)\end{array}$ & $\begin{array}{l}\text { Fat } \\
(\%)\end{array}$ & $\begin{array}{l}\text { crude protein } \\
(\%)\end{array}$ & $\begin{array}{c}\text { Crude fibre } \\
(\%)\end{array}$ & $\begin{array}{l}\text { Ash } \\
(\%)\end{array}$ & $\begin{array}{r}\mathrm{CHO} \\
(\%)\end{array}$ & $\begin{array}{c}\text { Energy ca } \\
\text { Value (Kcal) }\end{array}$ & $\begin{array}{l}\text { alcium } \\
\text { (g) }\end{array}$ \\
\hline \multicolumn{10}{|c|}{ FAO/WHO MINIMUM } \\
\hline & TANDARD & 4.00 & 24.00 & 26.00 & 0.00 & 0.00 & 38.00 & 465.00 & 1.00 \\
\hline \multirow[t]{2}{*}{$\mathbf{A}$} & Before & 62.10 & 13.57 & 10.62 & 0.05 & 1.70 & 11.96 & 298.55 & 0.301 \\
\hline & After & 5.01 & 35.41 & 28.02 & Nd & 0.00 & 31.56 & 557.01 & 0.311 \\
\hline \multirow[t]{2}{*}{$\mathbf{B}$} & Before & 45.00 & 12.67 & 15.08 & 0.00 & 4.00 & 23.25 & 276.86 & 0.313 \\
\hline & After & 0.00 & 23.04 & 27.42 & 0 & 1.00 & 48.54 & 511.20 & 0.310 \\
\hline \multirow[t]{2}{*}{$\mathbf{C}$} & Before & 52.00 & 15.82 & 18.67 & 0.05 & 1.50 & 11.96 & 279.15 & 0.301 \\
\hline & After & 0.00 & 32.96 & 38.90 & Nd & 1.00 & 27.14 & 560.80 & 0.304 \\
\hline
\end{tabular}

*Nd: Not detectable

Despite the slight deviations in compositions of some nutrients from FAO and WHO standards which may be due to the initial compositions of these nutrients in the raw cow milk, the energy value of the end products are beneficiary. These slight deviations can be overcome by improved method of production where the concentration of the initial raw milk can be regulated to suite the quality of the end product. The defects in calcium contents can also be augmented during cheese production. 


\section{Conclusions}

High temperature and long drying times in conventional drying cause serious damage to product nutrients and reduce the rehydration capacity of the dried product. The results of the proximate analysis on all the samples showed that despite the slight deviations of some nutritive components from the minimum standard values stipulated by FAO and WHO, the overall calorific values of the dried samples are higher than the minimum recommended standard value. The calcium content in all the dried samples remains approximately constant and lower than the standard recommended value due to low initial value of calcium in the samples before freeze drying. By these results of proximate analysis in this research, it can be said that the defects of nutritional degradation experienced during conventional drying methods are eliminated during the freeze drying of local cheese. With these, freeze drying can be a good option for drying local cheese in order to retain its nutrients and also increase its shelf-life for later human consumption.

\section{References}

[1] África C, and Susana S. (2011). Heat pump drying kinetics of a pressed type Cheese: LWT - $\quad$ Food $\quad$ Science and Technology 44, 489-494

[2] Bala B.K., Mondol, M.R.A., Biswas, B.K., Das Chowdury, B.L. and Janjai,S., (2003). Solar drying of pineapple using solar tunnel drier Renewable Energy 28, 183-190.

[3] Chakraborty R., Saha A.K. and Bhattacharya P. (2006).Modeling and simulation of parametric sensitivity in primary freeze-drying of food stuffs, Journal of Separation

[4] And Purification Technology, 49, 258-263.

[5] Charles, C.O. (1993). Traditional cheese making manual, Addis Abbaba: international livestock centre for Africa.

[6] Emmanuel C.N. (2000). Performance evaluation of a laboratory freeze dryer. A project submitted for the award of National Diploma in chemical Engineering at Federal polytechnic Bida.

[7] Erenturk, S. (2007). Comparison of genetic algorithm and neural network approaches for the drying process of carrot. J. Food Eng., 78: $905-912$.

[8] Gregory I.O. (2005). Food Analysis and instrumentation theory and practice: first edition, Lagos: HG Support Nigeria Limited.

[9] Marco G., Joao V. and Filipe O. (2010).Scale up methodology for pharmaceutical spray dying: www.hovione.com

[10] Mascarenhasa W.J, Akayavby H.U, and Pikal M.J (1997).A computational model for finite element analysis of the freeze-drying process. Computational Methods Applied Mechanical Engineering, 148, 105-124.

[11] Nastaj J.F and Witkiewicz K. (2009). Mathematical modeling of the primary and secondary vacuum freeze drying of random solids at microwave heating: International Journal of Heat and Mass Transfer, 52, 4796-4806.

[12] Ratti, C. (2001). Hot air and freeze drying of high value foods: Journal of food engineering 49, 311-319.

[13] Ricardson J.F, Harker J.H. and Backhust J.R. (2002). Chemical Engineering Volume 2: Fifth Edition,

Oxford: Butterworth Heinemann.

[14] Salvatore A. V. and Antonello A. B. (2008).Development of simplified models for the freeze-drying process and investigation of the optimal operating conditions: Journal of Chemical Engineering Research 86, 9-22,

[15] Stephen G. M, Gerhard S, Eva M. L, Axel M, Ulrich J.G, Doris E. B, Peter E W. and Nora A.U. (2011).The impact of spray drying outlet temperature on the particle morphology of mannitol: Journal of powder technology. 213, 27-35,

[16] Warren L.M. Julius C.S. and Peter H. (2005). Unit Operations of Chemical Engineering. Seventh edition, New York: Mc-Graw-Hill Companies Incorporation. 